\title{
Synthesis and biological evaluation of new
} I-(4,6-dimethylpyrimidin-2-yl)-I'-aryl/heteroaryl3,3'-dimethyl-(4,5'-bipyrazol)-5-ols \section{as antimicrobial agents}

\author{
This article was published in the following Dove Press journal: \\ Reports in Organic Chemistry \\ 6 April 2013 \\ Number of times this article has been viewed
}

\author{
Ranjana Aggarwal' \\ Chinu Rani' \\ Chetan Sharma ${ }^{2}$ \\ KR Aneja ${ }^{2}$ \\ 'Department of Chemistry, \\ ${ }^{2}$ Department of Microbiology, \\ Kurukshetra University, Kurukshetra, \\ Haryana, India
}

\begin{abstract}
Hydroxy-3-methyl-1-(4,6-dimethylpyrimidin-2-yl)pyrazol-4-yl-1,3-butanedione 4, obtained by the rearrangement of 2-(4,6-dimethylpyrimidin-2-yl)-1-[1-(4-hydroxy-6-methylpyran2-one-3-yl)ethylidene]hydrazine 3, afforded 1-(4,6-dimethylpyrimidin-2-yl)-1'-aryl/heteroaryl3,3'-dimethyl-(4,5'-bipyrazol)-5-ols (6) in excellent yields after treatment with various aryl/ heteroaryl hydrazines. The structures of the compounds were established by nuclear magnetic resonance $\left({ }^{1} \mathrm{H}\right.$ and $\left.{ }^{13} \mathrm{C}\right)$, infrared, and mass spectral data, and by elemental analysis. All the compounds synthesized were screened for their antibacterial activity against two Grampositive bacteria (Staphylococcus aureus and Bacillus subtilis) and two Gram-negative bacteria (Escherichia coli and Pseudomonas aeruginosa), and their antifungal activity against two yeasts (Candida albicans and Saccharomyces cerevisiae).
\end{abstract}

Keywords: 4,5'-bipyrazol-5-ol derivatives, antibacterial activity, antifungal activity

\section{Introduction}

The pyrazole nucleus represents a very attractive scaffold for obtaining novel molecules endowed with diverse biological activity, including anti-inflammatory, antidepressant, anticonvulsant, anticancer, analgesic, anthelmintic, antioxidant, and herbicidal properties. ${ }^{1-6}$ Celecoxib, a selective cyclo-oxygenase- 2 inhibitor, is used for the treatment of rheumatoid arthritis and osteoarthritis. ${ }^{7}$ Many other drugs, including lonazolac, aminopyrine, muzolimine, sulfaphenazole, and betazole, also contain a pyrazole nucleus. Moreno et al have recently described the synthesis of compounds containing a pyrazole moiety which exhibit in vitro and in vivo trypanosomicidal activity. ${ }^{8}$ Some bipyrazolyl derivatives have also proven to be useful as potential antitumor, anti-inflammatory, antibacterial, and cytotoxic agents. ${ }^{9-12}$ Smaail et al synthesized bipyrazole derivatives which have shown promising antibacterial and antifungal activity. ${ }^{13}$ Bipyrazoles, in particular, have been reported to be active components in capturing active oxygen and free radicals in vivo. They are also useful agents for preventing and treating various diseases induced by active oxygen. Some bipyrazoles have found application as agents for detecting singlet oxygen, ${ }^{14}$ and others have been synthesized and used as agents with central nervous system activity. ${ }^{15}$

Many classes of chemotherapeutic agents containing a pyrimidine nucleus are in clinical use, including sulfadiazine, sulfamerazine, sulfamethoxydiazine, and brodimoprim (antibacterials), flucytosine and hexitidine (antifungals), 5-flurouracil, ftorafur, and gemcitabine (antineoplastic agents), stavudine, iodoxuridine, trifluridine, and
Correspondence: Ranjana Aggarwal Department of Chemistry, Kurukshetra University, Kurukshetra I36 II9, Haryana, India

Tel +9| 1744238734

$\mathrm{Fax}+911744238277$

Email ranjanaaggarwal67@gmail.com 
zidovudine (antivirals), and pyrimethamine (an antimalarial). The most common method used for synthesis of pyrazoles and their derivatives involves the reaction of hydrazines with 1,3-dicarbonyl compounds or $\alpha, \beta$-unsaturated aldehydes or ketones. ${ }^{16-22}$ Recently, Zora et al reported the synthesis of some pyrazoles via electrophilic cyclization of $\alpha, \beta$-alkynic hydrazones. ${ }^{23,24}$ Synthesis of pyrazoles has also been accomplished by intermolecular 1,3-dipolar cycloaddition of diazoalkanes or nitrilimines with alkenes or alkynes. ${ }^{25-27}$ Reaction of dehydroacetic acid with phenylhydrazine to generate 4-(acylacetyl)-1-phenylpyrazolin-5-one and its synthetic applications to bipyrazol-5-ols and pyranopyrazoles has been studied by Gelin et al. ${ }^{28}$ In view of these observations and in continuation of our research program on the synthesis of bipyrazoles, ${ }^{29-31}$ we herein report the synthesis of some novel 4,5'-bipyrazol-5-ols containing a pyrimidine ring which have been found to have interesting antibacterial and antifungal activities.

\section{Materials and methods}

2-(4,6-Dimethylpyrimidin-2-yl)-1-[1-(4-hydroxy-6methylpyran-2-one-3-yl)ethylidene]hydrazine (3), obtained by the condensation of dehydroacetic acid (1) and 2-hydrazino-4,6-dimethylpyrimidine (2) in ethanol, on refluxing in acetic acid underwent rearrangement to yield the key intermediate, 5-hydroxy-3-methyl-1-(4,6-dimethylpyrimidin2-yl)pyrazol-4-yl-1,3-butanedione (4). Further, synthesis of title compounds, 1-(4,6-dimethylpyrimidin-2-yl)-1'-aryl/ heteroaryl-3,3'-dimethyl-(4,5'-bipyrazol)-5-ols (6), was achieved by the reaction of (4) with various aryl/heteroaryl hydrazines (5) in the presence of ethanol and concentrated $\mathrm{HCl}$ or ethanol/AcOH/sodium acetate (Figure 1).<smiles>CC(=O)c1c(O)cc(C)oc1=O</smiles>

1<smiles>Cc1cc(C)nc(NN)n1</smiles>

2<smiles></smiles>

6<smiles>C/C(=N\Nc1nc(C)cc(C)n1)c1c(O)cc(C)oc1=O</smiles>

3<smiles>CC(C)C=C[V]</smiles>
EtOH/AcOH/NaOAc<smiles>CC(=O)CC(=O)c1c(C)nn(-c2nc(C)cc(C)n2)c1O</smiles>

4

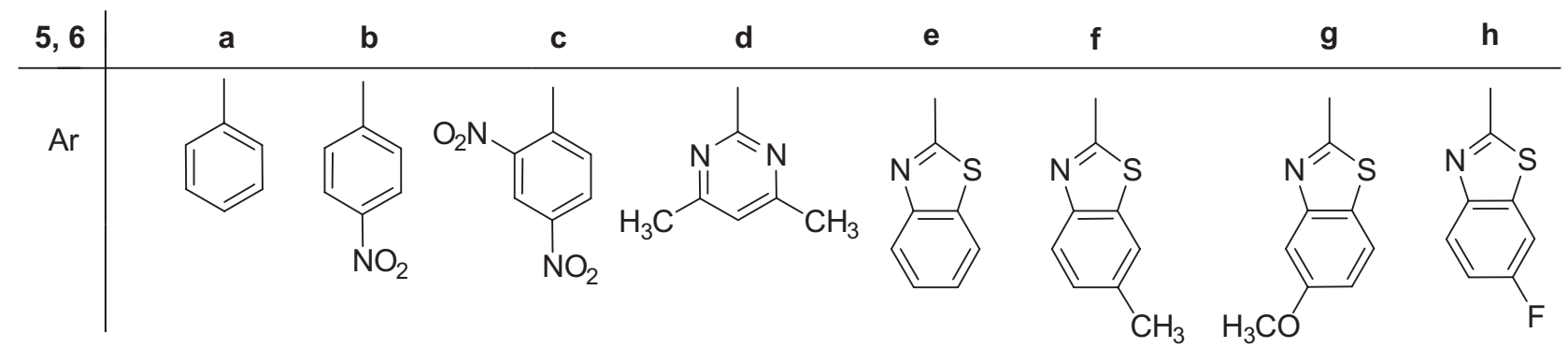

Figure I Synthesis of I-(4,6-dimethylpyrimidin-2-yl)-I'-aryl/heteroaryl-3,3'-dimethyl-(4,5'-bipyrazol)-5-ols (6) 
The plausible mechanism for these reaction steps is outlined in Figure 2. Initial nucleophilic attack of the amino group of hydrazine 2 on the carbonyl of the acetyl side chain at the 3 position of dehydroacetic acid 1 followed by loss of one molecule of water yielded hydrazone 3 . This hydrazone 3 then underwent rearrangement, involving a nitrogen nucleophilic attack at the $\mathrm{C}_{2}$ lactone carbonyl with ring opening, thus generating 4 . In the last step, this bielectrophilic pyrazolyl diketone 4 reacts with binucleophilic aryl/heteroaryl hydrazines to give 4,5'-bipyrazol-5-ols 6 (Figure 2). The structure of all the newly synthesized compounds was established on the basis of infrared, mass, nuclear magnetic resonance $\left({ }^{1} \mathrm{H}\right.$ and $\left.{ }^{13} \mathrm{C}\right)$ spectral data and elemental analysis. The infrared spectrum of 4 displayed absorption bands at $1551 \mathrm{~cm}^{-1}$ $(\mathrm{C}=\mathrm{N})$ and $1713 \mathrm{~cm}^{-1}(\mathrm{C}=\mathrm{O})$. The ${ }^{1} \mathrm{H}$ NMR spectrum of 4 indicated its existence in two forms, ie, a keto form (42\%) and an enol form (58\%), as shown in Figure 3. In the keto form, two methyl groups attached to the pyrimidine ring of $4 \mathrm{a}$ resonated as a singlet at about $\delta 2.54 \mathrm{ppm}$. Two singlets were also observed at about $\delta 2.04$ and $\delta 2.51 \mathrm{ppm}$, which correspond to a methyl attached to carbonyl and the other due to a $\mathrm{C}_{3}-\mathrm{CH}_{3}$ in the pyrazole ring, respectively. One singlet at<smiles>CCOC(=O)c1c(O)cc(C)oc1=O</smiles><smiles></smiles>

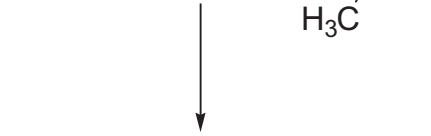<smiles>Cc1cc(C)nc(-n2nc(C)c(C(=O)CC(C)(C)C)c2O)n1</smiles>

$$
4
$$<smiles>Cc1cc(C)nc(-n2nc(C)c(-c3cc(C)nn3[Al])c2O)n1</smiles>

$-\mathrm{H}_{2} \mathrm{O}$<smiles>C/C(=N/Nc1nc(C)cc(C)n1)c1c(O)cc(C)oc1=O</smiles>

3

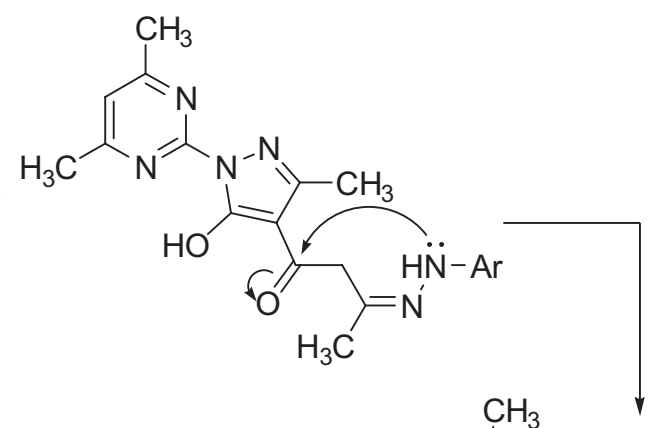<smiles>CC(C)=N</smiles><smiles>[3H]N1N=C(C)C(C)C1c1c(C)nn(C(C)=NC(=C)C)c1O</smiles>

Figure 2 Plausible mechanism of formation of I-(4,6-dimethylpyrimidin-2-yl)-I'-aryl/heteroaryl-3,3'-dimethyl-(4,5'-bipyrazol)-5-ols (6) 


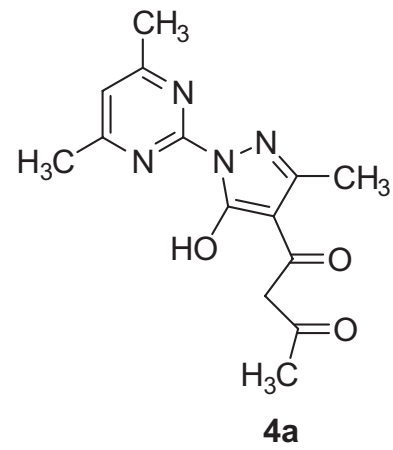

Keto form

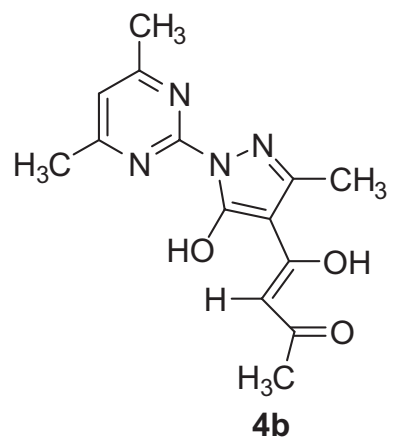

Enol form

Figure 3 Keto-enol tautomerism of 5-hydroxy-3-methyl-I-(4,6-dimethylpyrimidin-2-yl)pyrazol-4-yl-I,3-butanedione (4)

about $\delta 3.92 \mathrm{ppm}$ corresponding to methylene protons was also seen. One singlet was observed at about $\delta 6.95 \mathrm{ppm}$, corresponding to pyrimidine-5H. In enol form, one singlet at about $\delta 2.54 \mathrm{ppm}$ corresponding to two methyl groups attached to pyrimidine ring was observed. Two singlets at about $\delta 2.25$ and $\delta 2.48 \mathrm{ppm}$, corresponding to methyl attached to carbonyl and the other due to $\mathrm{C}_{3}-\mathrm{CH}_{3}$ of pyrazole ring, respectively, were seen. Two more singlets were also observed, one signal at about $\delta 6.16 \mathrm{ppm}$, due to a vinylic proton of enol form, and another at about $\delta 6.94 \mathrm{ppm}$, corresponding to pyrimidine- $5 \mathrm{H}$. One broad singlet was observed at about $\delta 16.19 \mathrm{ppm}$ due to enolic $\mathrm{OH}$.

The ${ }^{13} \mathrm{C}$ NMR of 4 also supports the existence of both a keto and an enol form. One signal at $\delta 30.62 \mathrm{ppm}$ due to a carbon on the methyl group attached to a carbonyl of keto form was observed. One more signal at $\delta 56.55 \mathrm{ppm}$ confirmed the presence of carbon attached to two carbonyl groups in keto form. One signal for vinylic carbon at $\delta$ $100.60 \mathrm{ppm}$ also confirmed the enol form. A signal at about $\delta 203.18 \mathrm{ppm}$ confirmed the presence of a carbonyl group attached to a methyl group in the keto form which shifted to $187.37 \mathrm{ppm}$ in the enol form. A signal at about $\delta 187.02 \mathrm{ppm}$ corresponding to another carbonyl group was seen, which shifted to $182.78 \mathrm{ppm}$ in the enol form.

The infrared spectrum of compound 6a displayed absorption bands at $3140 \mathrm{~cm}^{-1}$ (OH stretching), $1551 \mathrm{~cm}^{-1}$ $(\mathrm{C}=\mathrm{N}), 1651 \mathrm{~cm}^{-1}$, and $1597 \mathrm{~cm}^{-1}$ (aromatic region). The ${ }^{1} \mathrm{H}$ NMR spectra of $6(\mathrm{a}-\mathrm{h})$ displayed one singlet of six proton intensity at $\delta 2.57-2.60 \mathrm{ppm}$ due to two methyl groups at the pyrimidine nucleus. Two singlets of one proton intensity each also appeared at $\delta 6.29-6.36 \mathrm{ppm}$ and $\delta 6.93-6.97 \mathrm{ppm}$, corresponding to pyrazole- $4 \mathrm{H}$ and pyrimidine- $5 \mathrm{H}$, respectively, which is in accordance with the value reported in the literature. ${ }^{31,32}$ Two more singlets of three proton intensity were also observed, one at $\delta 2.42-2.46 \mathrm{ppm}$, and the position of the other methyl group was variable, ranging from $\delta 1.93$ to $\delta 2.44 \mathrm{ppm}$ in $6 \mathrm{a}-\mathrm{h}$, depending on the nature of the aryl/ heteroaryl group located on the pyrazole moiety. In compound 6a, one methyl group resonated at about $\delta 1.93$ and the other at about $\delta 2.42 \mathrm{ppm}$. It has earlier been observed, using nuclear overhauser enhancement techniques, that the upfield signal belongs to the pyrazole of the methyl group of pyrazolone $\left(\mathrm{C}_{3}-\mathrm{CH}_{3}\right)$, while the downfield signal is due to the methyl group located on the pyrazole moiety $\left(\mathrm{C}_{3^{\prime}}-\mathrm{CH}_{3}\right){ }^{31}$ This unexpected shielding of $\mathrm{C}_{3}-\mathrm{CH}_{3}$ may be attributed to the fact that these protons fall in the shielding zone of the phenyl ring. ${ }^{29,31}$ As we go from 6a to 6c, with an increase in the withdrawing nature of electrons and bulk of the aryl group, the $\mathrm{C}_{3}-\mathrm{CH}_{3}$ protons which fall in the shielding zone of the aryl ring become somewhat deshielded and resonate at about $\delta 2.13$ and $2.21 \mathrm{ppm}$ in $6 \mathrm{~b}$ and $6 \mathrm{c}$, respectively. However, the signal due to $\mathrm{C}_{3},-\mathrm{CH}_{3}$ remains almost constant. Similarly, in $6 \mathrm{~d}$, a marked shift in the position of the signal due to $\mathrm{C}_{3}-\mathrm{CH}_{3}$ was observed with $\delta 2.42 \mathrm{ppm}$, but the position of the signal due to $\mathrm{C}_{3},-\mathrm{CH}_{3}$ was not altered as compared with $6 \mathrm{a}$. When the phenyl group at position-1, of $6 \mathrm{a}$ is replaced by a bulkier and electron-withdrawing benzothiazole moiety, as in compounds $6 \mathrm{e}-\mathrm{h}$, the $\mathrm{C}_{3}-\mathrm{CH}_{3}$ and $\mathrm{C}_{3^{\prime}}-\mathrm{CH}_{3}$ protons resonated at $\delta 2.21-2.22 \mathrm{ppm}$ and $\delta 2.44-2.45 \mathrm{ppm}$, respectively. Thus, it was confirmed that the presence of a phenyl group at position-1, of 6a shields the protons of the methyl group at position-3, but when the phenyl group is replaced by a bulkier and electron-withdrawing substituent, deshielding occurs. An increase in the bulk at position-1, of 6 helps the molecule to attain planarity, thus reducing the shielding of the methyl group considerably. The bulkier the group, the more planar the molecule, and the less the variation in chemical shifts of $\mathrm{C}_{3}-\mathrm{CH}_{3}$ and $\mathrm{C}_{3^{\prime}}-\mathrm{CH}_{3}$. Further, the ${ }^{13} \mathrm{C}$ NMR spectra of $6 \mathrm{a}$ confirmed the presence of two carbons from methyl groups attached to the pyrimidine nucleus, by exhibiting signals at 
about $\delta 23.96 \mathrm{ppm}$ and two more signals at about $\delta 13.65$ and $13.52 \mathrm{ppm}$ for two carbons from methyl groups attached to pyrazole rings, respectively. A signal at $\delta 116.91 \mathrm{ppm}$ was assigned to $\mathrm{C}_{5}$ of the pyrimidine nucleus, as reported in literature. ${ }^{33}$ Further, the $\mathrm{C}_{4}$ of pyrazolone and the $\mathrm{C}_{4^{\prime}}$ of pyrazole nuclei resonated at about $\delta 93.65$ and $109.06 \mathrm{ppm}$, which is also in agreement with the literature. ${ }^{31}$ The complete assignment of carbon signals of the compounds 6 are given in Table 1.

\section{Antimicrobial activity}

All the compounds synthesized $(6 a-h)$ were assayed in vitro for their antibacterial and antifungal activity against two Gram-positive bacteria (Staphylococcus aureus MTCC 96 and Bacillus subtilis MTCC 121), two Gram-negative bacteria (Escherichia coli MTCC 1652 and Pseudomonas aeruginosa MTCC 741), and two yeasts, Candida albicans (MTCC 227) and Saccharomyces cerevisiae (MTCC 170).

Ciprofloxacin and amphotericin B were used as the standard drugs for evaluating antibacterial and antifungal activity, respectively. The zones of inhibition of antimicrobial activity are summarized in Table 2 . The observed minimum inhibitory concentrations (MIC) presented in Table 3 were in accordance with the results obtained in the primary screening. All the tested compounds $(6 \mathrm{a}-\mathrm{h})$ have shown moderate to good activity against the Gram-positive bacteria and the yeast, S. cerevisiae. However, only four compounds (6a, 6e, 6f, and 6g) were found to be active against Gramnegative $E$. coli bacteria. None of the compounds exhibited any activity against Gram-negative $P$. aeruginosa bacteria and the yeast $C$. albicans. On the basis of the maximum inhibitory activity shown against Gram-positive bacteria and yeast, compound $6 \mathrm{f}$ was found to be the most effective against $B$. subtilis, $S$. aureus, and S. cerevisiae, with zones of inhibition of $23.6 \mathrm{~mm}, 21.6 \mathrm{~mm}$, and $15.6 \mathrm{~mm}$, respectively (Table 2 and Figure 4), which are comparable with that of the commercial drugs, ciprofloxacin and amphotericin B. Compound 6f, which was found to be the most active, contains a benzothiazole moiety substituted at the 6-position by a methyl group. As we go from $6 \mathrm{f}$ to $6 \mathrm{~g}$, both the position and nature of the substituent at the benzothiazole moiety changes from 6-methyl to 5-methoxy, and somewhat of a decrease in activity was observed (Table 2 ). When the substituent at the benzothiazole moiety was removed, as in 6e, a further decrease in activity was observed. However, in the case of $6 \mathrm{~h}$, where a benzothiazole moiety is substituted by

Table I ${ }^{13} \mathrm{C}$ NMR data of compounds $6 \mathrm{a}-\mathrm{h}$

\begin{tabular}{|c|c|c|c|c|c|c|c|c|}
\hline Carbon & $6 a$ & $6 b$ & $6 c$ & 6d & $6 e$ & $6 f$ & $6 \mathrm{~g}$ & $6 \mathrm{~h}$ \\
\hline \multicolumn{9}{|c|}{ Pyrazole } \\
\hline $\mathrm{C}_{3}$ & 149.49 & 149.70 & 150.89 & 150.80 & 151.06 & 149.00 & 149.38 & | 47.59 \\
\hline $\mathrm{C}_{4}$ & 93.65 & 93.59 & 91.33 & 94.82 & 92.85 & 92.91 & 92.73 & 92.74 \\
\hline$C_{5}$ & 154.02 & I54.04 & 153.85 & $|53.3|$ & 154.72 & I54.68 & 154.84 & |54.7| \\
\hline $3-\mathrm{CH}_{3}$ & 13.52 & 13.54 & 13.29 & 13.66 & 13.82 & 13.80 & 13.76 & 13.78 \\
\hline$C_{3}^{\prime}$ & $|5| .78$ & 151.77 & 152.40 & 151.72 & 152.49 & 152.28 & 152.48 & 152.59 \\
\hline$C_{4}^{\prime}$ & 109.06 & 109.05 & 110.15 & 110.89 & 112.42 & 112.19 & 112.45 & $\mathrm{I} 12.47$ \\
\hline $\mathrm{C}_{5}^{\prime}$ & 133.22 & 133.28 & 135.12 & 134.85 & 133.25 & 133.38 & 133.48 & 134.14 \\
\hline $3^{\prime}-\mathrm{CH}_{3}$ & 13.65 & 13.65 & 13.53 & 13.79 & 13.99 & 13.98 & 13.95 & 13.96 \\
\hline \multicolumn{9}{|c|}{ Pyrimidine } \\
\hline$C_{2}$ & 156.72 & 156.69 & 156.26 & 156.68 & 156.84 & 156.84 & 156.82 & 156.83 \\
\hline $\mathrm{C}_{4}{ }^{\prime} \mathrm{C}_{6}$ & 168.73 & I 68.77 & 168.73 & 168.69 & 168.76 & 168.75 & 168.74 & 168.78 \\
\hline $\mathrm{C}_{5}$ & $116.9 \mid$ & I I 6.97 & 117.35 & I I6.7I & I 16.95 & 116.93 & 116.95 & I 16.97 \\
\hline $\mathrm{CH}_{3}$ & 23.96 & 23.99 & 23.82 & 23.78 & 24.01 & 24.01 & 24.01 & 24.00 \\
\hline \multicolumn{9}{|c|}{ Aryl/heteroaryl } \\
\hline$C_{1}$ & |40.57 & 140.46 & 144.12 & - & - & - & - & - \\
\hline $\mathrm{C}_{2}$ & 123.74 & 126.76 & 138.34 & 156.58 & 159.27 & I 58.44 & 159.65 & $|58.9|$ \\
\hline $\mathrm{C}_{3}$ & 128.87 & 128.92 & 120.68 & - & - & - & - & - \\
\hline $\mathrm{C}_{4}$ & 126.68 & | 43.52 & $|45.4|$ & $|68.5|$ & 121.04 & 120.87 & 120.34 & 123.67 \\
\hline $\mathrm{C}_{5}$ & - & - & 127.18 & I I7.38 & 124.52 & 127.55 & 154.65 & $|07.3|$ \\
\hline $\mathrm{C}_{6}$ & 123.74 & 126.76 & 128.75 & |68.5 | & 126.09 & |34.6 | & 119.56 & 134.28 \\
\hline $\mathrm{C}_{7}$ & - & - & - & - & 122.89 & 122.46 & 129.76 & I 14.59 \\
\hline $\mathrm{C}_{8}$ & - & - & - & - & |52.7| & |52.7| & 152.74 & 152.65 \\
\hline $\mathrm{C}_{9}$ & - & - & - & - & 134.69 & 134.56 & 134.67 & 134.63 \\
\hline \multicolumn{9}{|l|}{ Others } \\
\hline $\mathrm{CH}_{3}$ & - & - & - & 23.78 & - & 21.47 & - & - \\
\hline $\mathrm{OCH}_{3}$ & & & & & & & 55.34 & \\
\hline
\end{tabular}


Table 2 In vitro antimicrobial activity of compounds 6a-h using the agar diffusion assay technique

\begin{tabular}{|c|c|c|c|c|c|c|}
\hline \multirow[t]{3}{*}{ Compound } & \multicolumn{6}{|c|}{ Diameter of zone of growth inhibition $(\mathrm{mm})^{a}$} \\
\hline & \multicolumn{2}{|c|}{ Gram-positive bacteria } & \multicolumn{2}{|c|}{ Gram-negative bacteria } & \multicolumn{2}{|l|}{ Yeasts } \\
\hline & S. aureus & B. subtilis & E. coli & P. aeruginosa & S. cerevisiae & C. albicans \\
\hline $6 a$ & 17.6 & 19.3 & 13.6 & - & 12.3 & - \\
\hline $6 b$ & 15.6 & 17.6 & - & - & 12.6 & - \\
\hline $6 c$ & 16.3 & 17.3 & - & - & 13.6 & - \\
\hline $6 d$ & 15.6 & 17.6 & - & - & 12.6 & - \\
\hline $6 e$ & 17.3 & 19.3 & 12.3 & - & 13.0 & - \\
\hline $6 f$ & 21.3 & 23.6 & 16.3 & - & 15.6 & - \\
\hline $6 g$ & 20.6 & 22.6 & 15.6 & - & 14.3 & - \\
\hline $6 \mathrm{~h}$ & 18.3 & 19.3 & - & - & 12.3 & - \\
\hline Ciprofloxacin & 26.6 & 24.0 & 25.0 & 22.0 & - & - \\
\hline Amphotericin B & - & - & - & - & 19.3 & 16.6 \\
\hline
\end{tabular}

Notes: -, no activity; ${ }^{\text {avalues, }}$ including diameter of the well $(8 \mathrm{~mm})$, are means of three replicates.

Abbreviations: S. aureus, Staphylococcus aureus; E. coli, Escherichia coli; P. aeruginosa, Pseudomonas aeruginosa; C. albicans, Candida albicans; S. cerevisiae, Saccharomyces cerevisiae; B. subtilis, Bacillus subtilis.

a fluoro group at the 6-position, a complete loss of activity against Gram-negative bacteria and a decrease in activity against Gram-positive bacteria and yeast was observed when compared with $6 \mathrm{f}$. Compound $6 \mathrm{a}$ containing a phenyl group showed moderate activity. However, in compounds $6 \mathrm{~b}-\mathrm{d}$, the activity further decreased on changing the group from phenyl to $p$-nitrophenyl, 2,4-dinitrophenyl, and 4,6-dimethylpyrimidyl (Table 2).

The MIC of the various chemical compounds tested was in the range of $16-256 \mu \mathrm{g} / \mathrm{mL}$ against bacteria and $64-128 \mu \mathrm{g} / \mathrm{mL}$ against yeasts. Compound $6 \mathrm{f}$ exhibited the most promising results, showing the lowest MIC of $32 \mu \mathrm{g} / \mathrm{mL}$ against $S$. aureus, $16 \mu \mathrm{g} / \mathrm{mL}$ against $B$. subtilis, and $64 \mu \mathrm{g} / \mathrm{mL}$ against $S$. cerevisiae (Table 3 ). In conclusion, compounds having a phenyl group (6a) and a benzothiazole moiety (6e, $6 \mathrm{f}$ and $6 \mathrm{~g}$ ) showed activity against both Gram-positive bacteria, Gram-negative bacteria, and the yeast, $S$. cerevisiae. Among

Table 3 Minimum inhibitory concentration $(\mu \mathrm{g} / \mathrm{mL})$ values for compounds $6 \mathrm{a}-\mathrm{h}$ and reference drugs against the study microorganisms

\begin{tabular}{lllll}
\hline Compound & S. aureus & B. subtilis & E. coli & S. cerevisiae \\
\hline 6a & 128 & 64 & 256 & 128 \\
6b & 128 & 128 & - & 128 \\
6c & 128 & 128 & - & 128 \\
6d & 128 & 128 & - & 128 \\
6e & 128 & 64 & 512 & 128 \\
6f & 32 & 16 & 128 & 64 \\
6g & 64 & 32 & 256 & 128 \\
6h & 64 & 64 & - & 128 \\
Ciprofloxacin & 6.25 & 6.25 & - & - \\
Amphotericin B & - & - & 6.25 & 12.5 \\
\hline
\end{tabular}

Abbreviations: S. aureus, Staphylococcus aureus; E. coli, Escherichia coli; S. cerevisiae, Saccharomyces cerevisiae; B. subtilis, Bacillus subtilis. all the tested chemical compounds, compound $6 \mathrm{f}$ containing a 6-methyl-substituted benzothiazole moiety, was found to be the most effective for inhibiting the growth of Grampositive bacteria, Gram-negative bacteria, and yeasts, so this compound could be probed further as an antimicrobial agent with application in the pharmaceutical industry, after testing its toxicity in humans.

\section{Experimental studies}

Melting points were determined in open capillaries and are uncorrected. Infrared spectra were recorded on a spectrophotometer (IR M-500, Buck Scientific Inc, Norwalk, $\mathrm{CT})$ in $\mathrm{KBr}$ pellets $\left(v_{\max }\right.$ in $\left.\mathrm{cm}^{-1}\right)$. ${ }^{1} \mathrm{H}$ and ${ }^{13} \mathrm{C}$ NMR spectra for analytical purposes were recorded in $\mathrm{CDCl}_{3}$ on a Bruker instrument (Billerica, MA) at $300 \mathrm{MHz}$ and $75 \mathrm{MHz}$, respectively. Tetramethylsilane was taken as an internal standard. Chemical shifts $(\delta)$ were measured in ppm. Coupling constants $(\mathrm{J})$ are given in Hertz $(\mathrm{Hz})$.

2-Hydrazino-4,6-dimethylpyrimidine, 2-hydrazino-6substituted benzothiazole, and 2-hydrazino-5-substituted benzothiazole were prepared following a method already reported in the literature. ${ }^{34,35}$ Dehydroacetic acid, phenyl hydrazine, $p$-nitrophenyl hydrazine, and 2,4-dinitrophenyl hydrazine were commercially available.

\section{Preparation of 2-(4,6-dimethylpyrimidin- 2-yl)-I-[I-(4-hydroxy-6-methylpyran-2- one-3-yl)ethylidene] hydrazine (3)}

2-hydrazino-4,6-dimethylpyrimidine (1.38 g, $0.01 \mathrm{~mol})$ was added to an ethanolic solution of dehydroacetic acid $(1.68 \mathrm{~g}, 0.01 \mathrm{~mol})$, and the contents were allowed to reflux for 6 hours. The progress of the reaction was monitored by 


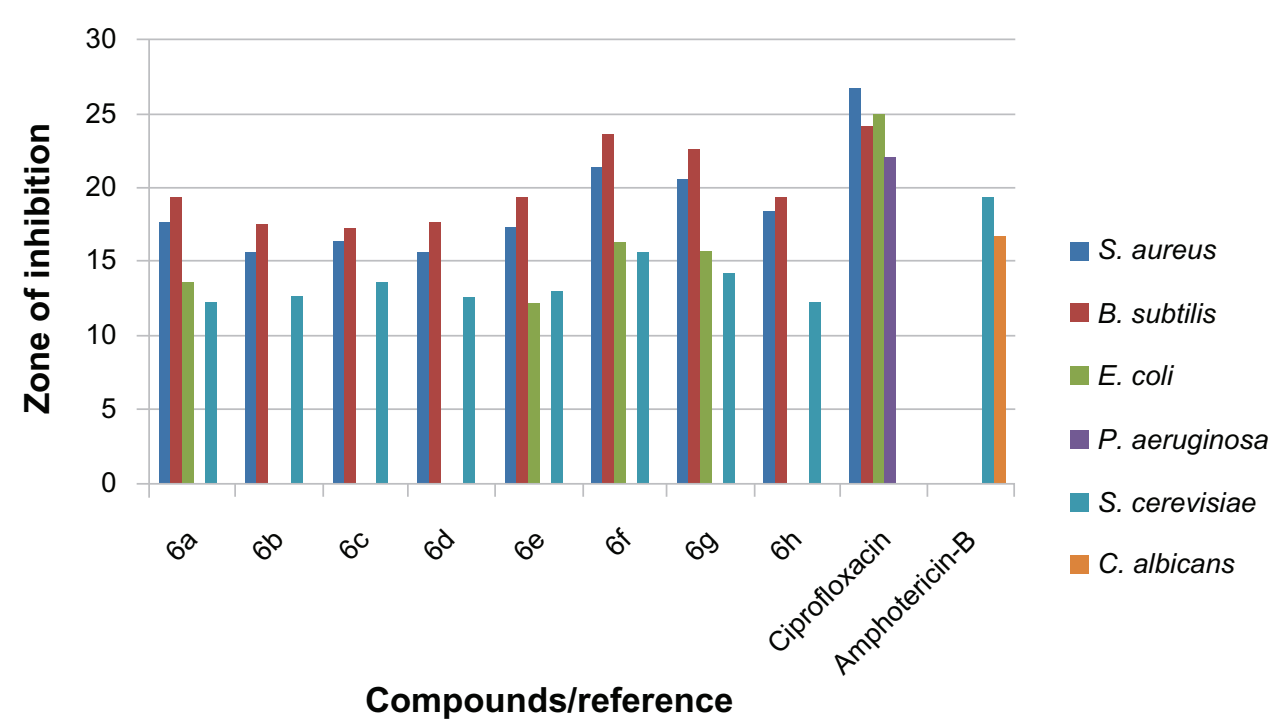

Figure 4 In vitro antimicrobial assay of test compounds/reference at concentration $4 \mathrm{mg} / \mathrm{mL}$.

Abbreviations: S. aureus, Staphylococcus aureus; E. coli, Escherichia coli; P. aeruginosa, Pseudomonas aeruginosa; C. albicans, Candida albicans; S. cerevisiae, Saccharomyces cerevisiae; B. subtilis, Bacillus subtilis.

thin layer chromatography. On completion of the reaction, the reaction mixture was allowed to cool. A yellow solid separated out which was filtered and washed with cold ethanol.

Yield $88 \%$; melting point $178^{\circ} \mathrm{C}-180^{\circ} \mathrm{C}$ (literature melting point $\left.180^{\circ} \mathrm{C}\right) ;{ }^{36} \mathrm{IR}\left(\mathrm{KBr}, \mathrm{cm}^{-1}\right): 1705(\mathrm{C}=\mathrm{O}), 1643$, 1597, 1551, 1443, 1358; ${ }^{1} \mathrm{H}$ NMR (300 MHz, $\left.\mathrm{CDCl}_{3}\right) \delta$ : $2.22\left(\mathrm{~s}, 3 \mathrm{H},-\mathrm{CH}_{3}\right), 2.42\left(\mathrm{~s}, 6 \mathrm{H}, \mathrm{C}_{4}-\mathrm{CH}_{3}, \mathrm{C}_{6}-\mathrm{CH}_{3}\right), 2.65$ $\left(\mathrm{s}, 3 \mathrm{H},-\mathrm{CH}_{3}\right), 5.91(\mathrm{~s}, 1 \mathrm{H}$, pyrone-5-H), $6.62(\mathrm{~s}, 1 \mathrm{H}$, pyrimidine-5-H)

\section{Preparation of 5-hydroxy-3-methyl-I - (4,6-dimethylpyrimidin-2-yl)pyrazol-4-yl- I,3-butanedione (4)}

Hydrazone of dehydroacetic acid 3 (2.88 g, $0.01 \mathrm{~mol})$ was dissolved in about $15 \mathrm{~mL}$ of acetic acid and the solution was allowed to reflux for about 45 minutes. The reaction mixture was poured in cold water, extracted with dichloromethane, and the solvent was distilled off to obtain a solid which was recrystallized from ethanol.

Yield $74 \%$; melting point $195^{\circ} \mathrm{C}-198^{\circ} \mathrm{C}$; IR $(\mathrm{KBr}$, $\left.\mathrm{cm}^{-1}\right): 1713(\mathrm{C}=\mathrm{O}), 1551,1427,1373 ;{ }^{1} \mathrm{H}$ NMR $(300 \mathrm{MHz}$, $\left.\mathrm{CDCl}_{3}\right) \delta$ : keto form; $2.04\left(\mathrm{~s},-\mathrm{CH}_{3}\right), 2.51\left(\mathrm{~s}, 3-\mathrm{CH}_{3}\right)$, 2.54 (s, pyrimidine-4, 6- $\left.\mathrm{CH}_{3}\right), 3.92\left(\mathrm{~s}, \mathrm{COCH}_{2} \mathrm{CO}\right), 6.95$ (s, $1 \mathrm{H}$, pyrimidine-5-H), enol form; $2.25\left(\mathrm{~s},-\mathrm{CH}_{3}\right), 2.48$ (s, 3- $\left.\mathrm{CH}_{3}\right), 2.54$ (s, pyrimidine-4, 6- $\left.\mathrm{CH}_{3}\right), 6.16(\mathrm{~s}, 1 \mathrm{H}$, vinylic), 16.19 (bs, enolic-OH); ${ }^{13} \mathrm{C}$ NMR $\left(75 \mathrm{MHz}, \mathrm{CDCl}_{3}\right.$ ) $\delta: 15.47,15.87,23.85,23.99,30.62,56.55,97.97,100.66$,
$104.28,117.48,117.63,153.57,154.06,156.23,156.32$, 157.91, 159.49, 168.81, 182.78, 187.02, 187.37, 203.18; MS (m/z): $289.17\left([\mathrm{M}+\mathrm{H}]^{+}\right)$; Analysis calculated for $\mathrm{C}_{14} \mathrm{H}_{16} \mathrm{~N}_{4} \mathrm{O}_{3}: \mathrm{C}, 58.32 ; \mathrm{H}, 5.59 ; \mathrm{N}, 19.43$. Found: C, 58.42; $\mathrm{H}, 5.55 ; \mathrm{N}, 19.40$.

\section{Preparation of I-(4,6-dimethylpyrimidin- 2-yl)- I'-aryl-3,3'-dimethyl-(4,5'- bipyrazol)-5-ols (6)}

To an ethanolic solution of 4 ( $2.88 \mathrm{~g}, 0.01 \mathrm{~mol})$, appropriately substituted aryl/heteroaryl hydrazine $5(0.01 \mathrm{~mol})$ was added, followed by $4-5$ drops of concentrated $\mathrm{HCl}$ or $\mathrm{AcOH} /$ sodium acetate $(0.01 \mathrm{~mol})$. The contents were allowed to reflux for 5-6 hours. The progress of the reaction was monitored by thin layer chromatography. The solid obtained after concentrating and cooling the reaction mixture was filtered and recrystallized from ethanol.

I-(4,6-dimethylpyrimidin-2-yl)-I'-phenyl-3,3'dimethyl-(4,5'-bipyrazol)-5-ols (6a)

Yield $82 \%$; melting point $152^{\circ} \mathrm{C}-154^{\circ} \mathrm{C}$; IR $\left(\mathrm{KBr}, \mathrm{cm}^{-1}\right)$ : $3140(\mathrm{OH}), 3055,1651,1558,1504,1458,1335 ;{ }^{1} \mathrm{H}$ NMR (300 MHz, $\left.\mathrm{CDCl}_{3}\right) \delta: 1.93\left(\mathrm{~s}, 3 \mathrm{H}, \mathrm{C}_{3}-\mathrm{CH}_{3}\right), 2.42$ (s, 3H, $\left.\mathrm{C}_{3}{ }^{\prime}-\mathrm{CH}_{3}\right), 2.57$ (s, 6H, pyrimidine-4, 6- $\mathrm{CH}_{3}$ ), 6.29 (s, 1H, $\left.\mathrm{C}_{4}^{\prime}-\mathrm{H}\right), 6.93(\mathrm{~s}, 1 \mathrm{H}$, pyrimidine-5-H), 7.21-7.34 (m, 3H, Ph 3, 4, 5-H), 7.41-7.44 (m, 2H, Ph 2, 6-H); MS (m/z): $361.23\left([\mathrm{M}+\mathrm{H}]^{+}\right)$; analysis calculated for $\mathrm{C}_{20} \mathrm{H}_{20} \mathrm{~N}_{6} \mathrm{O}: \mathrm{C}, 66.65$; H, 5.59; N, 23.32. Found: C, 66.67; H, 5.55; N, 23.30. 
I-(4,6-dimethylpyrimidin-2-yl)-I'-(4-nitrophenyl)3,3'-dimethyl-(4,5'-bipyrazol)-5-ol (6b)

Yield $65 \%$; melting point $220^{\circ} \mathrm{C}(\mathrm{d})$; IR $\left(\mathrm{KBr}, \mathrm{cm}^{-1}\right): 3148$ (OH), 1651, 1597, 1551, 1504, 1466, 1381, 1342; ${ }^{1} \mathrm{H}$ NMR $\left(300 \mathrm{MHz}, \mathrm{CDCl}_{3}\right) \delta: 2.13\left(\mathrm{~s}, 3 \mathrm{H}, \mathrm{C}_{3}-\mathrm{CH}_{3}\right), 2.42$ $\left(\mathrm{s}, 3 \mathrm{H}, \mathrm{C}_{3}{ }^{\prime}-\mathrm{CH}_{3}\right), 2.58\left(\mathrm{~s}, 6 \mathrm{H}\right.$, pyrimidine $\left.-4,6-\mathrm{CH}_{3}\right), 6.33$ $\left(\mathrm{s}, 1 \mathrm{H}, \mathrm{C}_{4}{ }^{\prime}-\mathrm{H}\right), 6.97(\mathrm{~s}, 1 \mathrm{H}$, pyrimidine-5- $\mathrm{H}), 7.65(\mathrm{~d}, 2 \mathrm{H}$, $J=7.2 \mathrm{~Hz}, \mathrm{Ph}-2,6-\mathrm{H}), 8.19$ (d, 2H, $J=7.2 \mathrm{~Hz}, \mathrm{Ph}-3$, 5-H); MS (m/z): $406.22\left([\mathrm{M}+\mathrm{H}]^{+}\right)$; analysis calculated for $\mathrm{C}_{20} \mathrm{H}_{19} \mathrm{~N}_{7} \mathrm{O}_{3}: \mathrm{C}, 59.25 ; \mathrm{H}, 4.72 ; \mathrm{N}, 24.18$. Found: C, 59.23; H, 4.76; N, 24.23.

I-(4,6-dimethylpyrimidin-2-yl)-I'-(2,4-dinitrophenyl)3,3'-dimethyl-(4,5'-bipyrazol)-5-ol (6c)

Yield $78 \%$; melting point $228^{\circ} \mathrm{C}-232^{\circ} \mathrm{C}$; IR ( $\mathrm{KBr}$, $\left.\mathrm{cm}^{-1}\right): 3141(\mathrm{OH}), 1651,1597,1528,1458,1335 ;{ }^{1} \mathrm{H}$ NMR (300 MHz, $\left.\mathrm{CDCl}_{3}\right) \delta: 2.21\left(\mathrm{~s}, 3 \mathrm{H}, \mathrm{C}_{3}-\mathrm{CH}_{3}\right), 2.46$ (s, 3H, $\mathrm{C}_{3}{ }^{\prime}-\mathrm{CH}_{3}$ ), 2.57 (s, 6H, pyrimidine-4, 6- $\mathrm{CH}_{3}$ ), 6.34 $\left(\mathrm{s}, 1 \mathrm{H}, \mathrm{C}_{4}{ }^{\prime}-\mathrm{H}\right), 6.95(\mathrm{~s}, 1 \mathrm{H}$, pyrimidine-5-H), $7.76(\mathrm{~d}, 1 \mathrm{H}$, $J=8.7 \mathrm{~Hz}, \mathrm{Ph}-6-\mathrm{H}), 8.40$ (d, 1H, $J=8.7 \mathrm{~Hz}, \mathrm{Ph}-5-\mathrm{H}), 8.69$ (s, 1H, Ph-3-H); MS (m/z): $451.23\left([\mathrm{M}+\mathrm{H}]^{+}\right)$; analysis calculated for $\mathrm{C}_{20} \mathrm{H}_{18} \mathrm{~N}_{8} \mathrm{O}_{5}$ : C, 53.33; H, 4.03; N, 24.88. Found: C, 53.28; H, 4.10; N, 24.85 .

I-(4,6-dimethylpyrimidin-2-yl)-I'-

(4,6-dimethylpyrimidin-2-yl)-3,3'-dimethyl-

(4,5'-bipyrazol)-5-ol (6d)

Yield $71 \%$; melting point $168^{\circ} \mathrm{C}-170^{\circ} \mathrm{C}$; IR $\left(\mathrm{KBr}, \mathrm{cm}^{-1}\right)$ : $3271(\mathrm{OH}), 2932,1643,1597,1551,1504,1427,1372 ;{ }^{1} \mathrm{H}$ $\operatorname{NMR}\left(300 \mathrm{MHz}, \mathrm{CDCl}_{3}\right) \delta: 2.42\left(\mathrm{~s}, 6 \mathrm{H}, \mathrm{C}_{3}-\mathrm{CH}_{3}, \mathrm{C}_{3}{ }^{\prime}-\mathrm{CH}_{3}\right)$, $2.57\left(\mathrm{~s}, 12 \mathrm{H}\right.$, pyrimidine-4, 6- $\left.\mathrm{CH}_{3}\right), 6.32\left(\mathrm{~s}, 1 \mathrm{H}, \mathrm{C}_{4}{ }^{\prime}-\mathrm{H}\right)$, $6.86(\mathrm{~s}, 1 \mathrm{H}$, pyrimidine $-5-\mathrm{H}), 6.91(\mathrm{~s}, 1 \mathrm{H}$, pyrimidine5-H); MS (m/z): $391.24\left([\mathrm{M}+\mathrm{H}]^{+}\right)$; analysis calculated for $\mathrm{C}_{20} \mathrm{H}_{22} \mathrm{~N}_{8} \mathrm{O}: \mathrm{C}, 61.52 ; \mathrm{H}, 5.68 ; \mathrm{N}, 28.70$. Found: $\mathrm{C}, 61.57$; $\mathrm{H}, 5.62 ; \mathrm{N}, 28.68$.

I-(4,6-dimethylpyrimidin-2-yl)-I'-(benzothiazol-2-yl)3,3'-dimethyl-(4,5'-bipyrazol)-5-ol (6e)

Yield $84 \%$; melting point $234^{\circ} \mathrm{C}-236^{\circ} \mathrm{C}$; IR $\left(\mathrm{KBr}, \mathrm{cm}^{-1}\right): 1720$ $(\mathrm{C}=\mathrm{O}), 1643,1605,1543,1435,1373 ;{ }^{1} \mathrm{H}$ NMR (300 MHz, $\left.\mathrm{CDCl}_{3}\right) \delta: 2.22\left(\mathrm{~s}, 3 \mathrm{H}, \mathrm{C}_{3}-\mathrm{CH}_{3}\right), 2.45\left(\mathrm{~s}, 3 \mathrm{H}, \mathrm{C}_{3}{ }^{\prime}-\mathrm{CH}_{3}\right), 2.60$ (s, 6H, pyrimidine-4, 6- $\left.\mathrm{CH}_{3}\right), 6.36\left(\mathrm{~s}, 1 \mathrm{H}, \mathrm{C}_{4}{ }^{\prime}-\mathrm{H}\right), 6.96$ (s, 1H, pyrimidine-5-H), 7.29-7.32 (m, 1H, benzothiazole5-H), 7.36-7.41 (m, 1H, benzothiazole-6-H), 7.75-7.82 (m, $2 \mathrm{H}$, benzothiazole-4, 7-H); MS (m/z): $418.18\left([\mathrm{M}+\mathrm{H}]^{+}\right)$; analysis calculated for $\mathrm{C}_{21} \mathrm{H}_{19} \mathrm{~N}_{7} \mathrm{OS}$ : C, 60.42; H, 4.59; N, 23.49. Found: C, 60.39; H, 4.62; N, 23.50.
I-(4,6-dimethylpyrimidin-2-yl)- I'(6-methylbenzothiazol-2-yl)-3,3'-dimethyl(4,5'-bipyrazol)-5-ol (6f)

Yield $88 \%$; melting point $118^{\circ} \mathrm{C}-120^{\circ} \mathrm{C}$; IR $\left(\mathrm{KBr}, \mathrm{cm}^{-1}\right)$ : $1713(\mathrm{C}=\mathrm{O}), 1651,1605,1543,1458,1435,1373 ;{ }^{1} \mathrm{H}$ NMR $\left(300 \mathrm{MHz}, \mathrm{CDCl}_{3}\right) \delta: 2.21\left(\mathrm{~s}, 3 \mathrm{H}, \mathrm{C}_{3}-\mathrm{CH}_{3}\right), 2.44$ (s, 3H, benzothiazole- $\left.\mathrm{C}_{6}-\mathrm{CH}_{3}\right), 2.45\left(\mathrm{~s}, 3 \mathrm{H}, \mathrm{C}_{3}{ }^{\prime}-\mathrm{CH}_{3}\right), 2.60$ $\left(\mathrm{s}, 6 \mathrm{H}\right.$, pyrimidine-4, 6- $\left.\mathrm{CH}_{3}\right), 6.36\left(\mathrm{~s}, 1 \mathrm{H}, \mathrm{C}_{4}{ }^{\prime}-\mathrm{H}\right), 6.96(\mathrm{~s}, 1 \mathrm{H}$, pyrimidine-5-H), 7.18-7.20 (m, 1H, benzothiazole-5-H), 7.55 (s, 1H, benzothiazole-7-H), 7.67-7.70 (m, 1H, benzothiazole4-H); MS (m/z): $432.23\left([\mathrm{M}+\mathrm{H}]^{+}\right)$; analysis calculated for $\mathrm{C}_{22} \mathrm{H}_{21} \mathrm{~N}_{7} \mathrm{OS}$ : C, 61.23; H, 4.91; N, 22.72. Found: C, 61.28; H, $4.89 ; \mathrm{N}, 22.68$.

\section{I-(4,6-dimethylpyrimidin-2-yl)-I'-}

(5-methoxybenzothiazol-2-yl)-3,3'-dimethyl-

(4,5'-bipyrazol)-5-ol (6g)

Yield $74 \%$; melting point $125^{\circ} \mathrm{C}-128^{\circ} \mathrm{C}$; $\mathrm{IR}\left(\mathrm{KBr}, \mathrm{cm}^{-1}\right): 1712$ $(\mathrm{C}=\mathrm{O}), 1642,1602,1537,1458,1373 ;{ }^{1} \mathrm{H}$ NMR $(300 \mathrm{MHz}$, $\left.\mathrm{CDCl}_{3}\right) \delta: 2.29\left(\mathrm{~s}, 3 \mathrm{H}, \mathrm{C}_{3}-\mathrm{CH}_{3}\right), 2.44\left(\mathrm{~s}, 3 \mathrm{H}, \mathrm{C}_{3}{ }^{\prime}-\mathrm{CH}_{3}\right)$, $2.60\left(\mathrm{~s}, 6 \mathrm{H}\right.$, pyrimidine-4, 6- $\left.\mathrm{CH}_{3}\right), 3.89\left(\mathrm{~s}, 3 \mathrm{H}, \mathrm{OCH}_{3}\right)$ $6.35\left(\mathrm{~s}, 1 \mathrm{H}, \mathrm{C}_{4}{ }^{\prime}-\mathrm{H}\right), 6.97(\mathrm{~s}, 1 \mathrm{H}$, pyrimidine $-5-\mathrm{H})$, 7.03-7.11 (m, 1H, benzothiazole-6-H), 7.72-7.75 (m, 1H, benzothiazole-4-H), 7.85-7.87 (m, 1H, benzothiazole7-H); MS (m/z): $448.19([\mathrm{M}+\mathrm{H}]+)$; analysis calculated for $\mathrm{C}_{22} \mathrm{H}_{21} \mathrm{~N}_{7} \mathrm{OS}$ : C, 59.05; H, 4.73; N, 21.91 Found: C, 58.99; $\mathrm{H}, 4.71 ; \mathrm{N}, 21.89$.

\section{I-(4,6-dimethylpyrimidin-2-yl)-I'-}

(6-fluorobenzothiazol-2-yl)-3,3'-dimethyl-

(4,5'-bipyrazol)-5-ol (6h)

Yield $86 \%$; melting point $138^{\circ} \mathrm{C}-140^{\circ} \mathrm{C}$; IR $\left(\mathrm{KBr}, \mathrm{cm}^{-1}\right)$ : $1713(\mathrm{C}=\mathrm{O}), 1651,1605,1551,1458,1381 ;{ }^{1} \mathrm{H}$ NMR $\left(300 \mathrm{MHz}, \mathrm{CDCl}_{3}\right) \delta: 2.22\left(\mathrm{~s}, 3 \mathrm{H}, \mathrm{C}_{3}-\mathrm{CH}_{3}\right), 2.44(\mathrm{~s}, 3 \mathrm{H}$, $\left.\mathrm{C}_{3}{ }^{\prime}-\mathrm{CH}_{3}\right), 2.59\left(\mathrm{~s}, 6 \mathrm{H}\right.$, pyrimidine-4, 6- $\left.\mathrm{CH}_{3}\right), 6.35(\mathrm{~s}, 1 \mathrm{H}$, $\left.\mathrm{C}_{4}{ }^{\prime}-\mathrm{H}\right), 6.96(\mathrm{~s}, 1 \mathrm{H}$, pyrimidine-5-H), 7.08-7.20 (dt, $1 \mathrm{H}$, $J=2.7 \mathrm{~Hz}, J=9.0 \mathrm{~Hz}$, benzothiazole $-5-\mathrm{H}), 7.43-7.47$ (dd, $1 \mathrm{H}, J=2.7 \mathrm{~Hz}, J=8.1 \mathrm{~Hz}$, benzothiazole-7-H), $7.70-7.75(\mathrm{dd}, 1 \mathrm{H}, J=4.8 \mathrm{~Hz}, J=9.0 \mathrm{~Hz}$, benzothiazole4-H); MS (m/z): $436.18\left([\mathrm{M}+\mathrm{H}]^{+}\right)$; analysis calculated for $\mathrm{C}_{21} \mathrm{H}_{18} \mathrm{FN}_{7} \mathrm{OS}$ : C, 57.92; H, 4.17; N, 22.51. Found: C, 57.89; $\mathrm{H}, 4.12 ; \mathrm{N}, 22.57$.

\section{Antimicrobial assay}

All the microbial cultures were sourced from the Microbial Type Culture Collection (MTCC, Imtech, Chandigarh). The microbial isolates representing Gram-negative and 
Gram-positive bacteria were subcultured on nutrient agar, whereas the yeast was subcultured on malt yeast agar. The screening of eight compounds $(6 \mathrm{a}-\mathrm{h})$ was done in vitro using the agar well diffusion method. ${ }^{37}$ The stock solutions ( $4 \mathrm{mg} / \mathrm{mL}$ ) of the test compounds were prepared by dissolving $4 \mathrm{mg}$ of test compound in $1 \mathrm{~mL}$ of dimethyl sulfoxide. All samples were sterilized through a $0.2 \mathrm{~mm}$ membrane filter and stored at $4{ }^{\circ} \mathrm{C}$ until further use. Microbial inoculums were prepared from 24-hour-old cultures and turbidity was adjusted equivalent to the $0.5 \mathrm{McFarland}$ turbidity standard, which is visually comparable with a microbial suspension of approximately $1.5 \times 10^{8} \mathrm{cfu} / \mathrm{mL}$. By inoculating $100 \mu \mathrm{L}$ of each test bacterial culture in $20 \mathrm{~mL}$ of warm, melted, autoclaved Mueller Hinton agar, seed layers were prepared (separate flasks were used for each bacterial culture). After mixing, these were poured into sterilized labeled Petri plates $(150 \mathrm{~mm} \times 20 \mathrm{~mm})$. The $8 \mathrm{~mm}$ wells were punched in the solidified Petri plates with the help of a sterile cork borer. Using a micropipette, $100 \mathrm{~mL}$ of each test compound (stock $4 \mathrm{mg} / \mathrm{mL}$ ) was added aseptically to the individual wells. The loaded plates were incubated in an upright position at $37^{\circ} \mathrm{C} \pm 1{ }^{\circ} \mathrm{C}$ for 24 hours. The diameter of the zone of growth inhibition around each well after incubation was measured in millimeters using a zone reader (HiAntibiotic zone scale, Table 2). Ciprofloxacin $4 \mathrm{mg} / \mathrm{mL}$ was used as the standard antibiotic for bacteria and amphotericin B for yeasts, with dimethyl sulfoxide as a negative control under similar conditions for comparison. This procedure was performed in three replicate plates for each organism.

\section{Determination of minimum inhibitory concentration}

The MIC is the lowest concentration of an antimicrobial compound that will inhibit visible growth of a microorganism after overnight incubation. The MIC of the various compounds against bacterial strains was tested using a modified agar well diffusion method. MICs were determined using the broth microdilution method, according to National Committee for Clinical Laboratory Standards recommendations. ${ }^{38}$ Testing was performed at $\mathrm{pH} 7.4 \pm 0.1$. The inoculums were prepared using a 16-hour broth culture of each bacterial strain adjusted to a turbidity equivalent to a $0.5 \mathrm{McFarland}$ standard, and diluted in Mueller Hinton agar broth medium to give a concentration of $1 \times 10^{6} \mathrm{cfu} / \mathrm{mL}$ for bacteria. The test compounds were dissolved in dimethyl sulfoxide to obtain $4 \mathrm{mg} / \mathrm{mL}$ stock solutions. To ensure that the solvent had no effect on microbial growth, a control test was performed using test medium supplemented with dimethyl sulfoxide at the same dilution as used in the experiments. A positive control (containing inoculum but no compound) and a negative control (medium only, without inoculum) were also prepared. Using this method, a two-fold serial dilution of each chemically synthesized compound was prepared by first reconstituting the compound in dimethyl sulfoxide followed by dilution in sterile distilled water to achieve a decreasing concentration range of 512 to $1 \mu \mathrm{g} /$ $\mathrm{mL}$. A $100 \mu \mathrm{L}$ volume of each dilution was introduced into wells (in triplicate) in the agar plates already seeded with $100 \mu \mathrm{L}$ of standardized inoculum $\left(10^{6} \mathrm{cfu} / \mathrm{mL}\right)$ of the test microbial strain. All test plates were incubated aerobically at $37^{\circ} \mathrm{C}$ for 24 hours and observed for the inhibition zones. MIC, taken as the lowest concentration of the chemical compound that completely inhibited the growth of bacteria, shown by a clear zone of inhibition, was recorded for each test organism. Ciprofloxacin was used as a positive control for bacteria and amphotericin B for yeast, with dimethylsulfoxide as a negative control.

\section{Conclusion}

We have synthesized novel 4,5'-bipyrazol-5-ols 6 (a-h), which has an interesting profile of antibacterial activity against Gram-positive and Gram-negative bacteria, as well as antifungal activity against yeasts.

\section{Acknowledgments}

We are grateful to the Council of Scientific and Industrial Research, New Delhi, India, for providing financial assistance to Chinu Rani, in the form of a Junior Research Fellowship and Senior Research Fellowship. Thanks are also extended to the Sophisticated Analytical Instrument Facility and the Central Drug Research Institute, Lucknow, for use of mass spectrometer facilities and elemental analyses.

\section{Disclosure}

The authors report no conflicts of interest in this work.

\section{References}

1. Szabo G, Fischer J, Kis-Varga A, Gyires K. New celecoxib derivatives as anti-inflammatory agents. J Med Chem. 2008;51:142-147.

2. Ozdemir Z, Kandilici HB, Gumusel B, Calis U, Bilgin AA. Synthesis and studies on antidepressant and anticonvulsant activities of some 3-(2-furyl)pyrazoline derivatives. Eur J Med Chem. 2007;42:373-379.

3. Gilbert AM, Failli A, Shumsky J, et al. Pyrazolidine-3,5-diones and 5-hydroxy-1H-pyrazol-3(2H)-ones, inhibitors of UDP- $N$-acetylenolpyruvyl glucosamine reductase. J Med Chem. 2006;49:6027-6036. 
4. Benaamane N, Nedjar-Kolli B, Bentarzi Y, et al. Synthesis and in silico biological activity evaluation of new N-substituted pyrazolo-oxazin-2one systems. Bioorg Med Chem. 2008;16:3059-3066.

5. Magedov IV, Manpadi M, Slambrouck SV, et al. Discovery and investigation of antiproliferative and apoptosis-inducing properties of new heterocyclic podophyllotoxin analogues accessible by a one-step multicomponent synthesis. J Med Chem. 2007;50:5183-5192.

6. Sivakumar KK, Rajasekaran A, Ponnilavarasan I, Somasundaram A, Sivasakthi R, Kamalaveni S. Synthesis and evaluation of anti-microbial and analgesic activity of some (4Z)-3-methyl-1-[(2-oxo-2H-chromen4-yl) carbonyl]-1H-pyrazole-4, 5-dione 4-[(4-substitutedphenyl) hydrazone]. Der Pharmacia Lettre. 2010;2:211-219.

7. Penning TD, Talley JJ, Bertenshaw SR, Carter JS, et al. Synthesis and biological evaluation of the 1,5-diarylpyrazole class of cyclooxygenase-2 inhibitors: identification of 4-[5-(4-methylphenyl)3-trifluoromethyl-1H-pyrazol-1-yl]benzenesulfonamide (SC-58635, celecoxib). J Med Chem. 1997;40:1347-1365.

8. Moreno MS, Marín C, Navarro P, et al. In vitro and in vivo trypanosomicidal activity of pyrazole-containing macrocyclic and macrobicyclic polyamines: their action on acute and chronic phases of Chagas disease. J Med Chem. 2012;55:4231-4243.

9. Smaail R, Yahya T, Nihed D, Olivier F, Olivier R. One pot synthesis and in vitro antitumor activity of some bipyrazolic tripodal derivatives. Lett Drug Des Discov. 2012;9:305-309.

10. Adnan AB, Tarek AA. Design, synthesis and biological evaluation of some pyrazole derivatives as anti-inflammatory-antimicrobial agents. Bioorg Med Chem. 2004;12:1935-1945.

11. Bouabdallahy I, Barekz L, Zyadz A, Ramdaniy A, Zidaney I, Melhaoui A. New pyrazolic compounds as cytotoxic agents. Nat Prod Res. 2007;21:298-302.

12. Siddiqui ZN, Asad M, Praveen S. Synthesis and biological activity of heterocycles from chalcone. Med Chem Res. 2008;17:318-325.

13. Smaail R, Yahya T, Imad H, et al. Synthesis, antibacterial and antifungal activities of some new bipyrazolic tripodal derivatives. Res J Chem Sci. $2012 ; 2: 40-44$

14. Takashi I, Kazuhisa S, Tetsuo O, Hietaro O, Hiroaki O, Hitoshi K. New sensitive agents for detecting singlet oxygen by electron spin resonance spectroscopy. Free Radical Bio Med. 1999;26:1339-1345.

15. Kosley RW, Macdonalds D, Sher R, inventors; Aventis Pharmaceuticals Inc. Dipyrazole compounds and their use as central nervous system agents. United States patent US 8053458B2. November 8, 2011.

16. Fustero S, Roman R, Sanz-Cervera JF, Simon-Fuentes A, Bueno J, Villanova S. Synthesis of new fluorinated tebufenpyrad analogs with acaricidal activity through regioselective pyrazole formation. $J$ Org Chem. 2008;73:8545-8552.

17. Huang YR, Katzenellenbogen JA. Regioselective synthesis of 1,3,5triaryl-4-alkylpyrazoles: novel ligands for the estrogen receptor. Org Lett. 2000;2:2833-2836.

18. Katritzky AR, Wang M, Zhang S, Voronkov MV, Steel PJ. Regioselective synthesis of polysubstituted pyrazoles and isoxazoles. J Org Chem. 2001;66:6787-6791.

19. Heller ST, Nartarajan SR. 1,3-Diketones from acid chlorides and ketones: a rapid and general one-pot synthesis of pyrazoles. Org Lett. 2006;8:2675-2678.

20. Polshettiwar V, Varma RS. Greener and rapid access to bio-active heterocycles: room temperature synthesis of pyrazoles and diazepines in aqueous medium. Tetrahedron Lett. 2008;49:397-400.
21. Grotjahn DB, Van S, Combs D, et al. New flexible synthesis of pyrazoles with different, functionalized substituents at C3 and C5. J Org Chem. 2002;67:9200-9209.

22. Dastrup DM, Yap AH, Weinreb SM, Henryb JR, Lechleiter AJ. Synthesis of $\beta$-tosylethylhydrazine and its use in preparation of N-protected pyrazoles and 5-aminopyrazoles. Tetrahedron. 2004;60:901-906.

23. Zora M, Kivrak A, Yazici C. Synthesis of pyrazoles via electrophilic cyclization. J Org Chem. 2011;76:6726-6742.

24. Zora M, Kivrak A. Synthesis of pyrazoles via CuI-mediated electrophilic cyclizations of $\alpha, \beta$-alkynic hydrazones. J Org Chem. 2011;76: 9379-9390.

25. Nakano Y, Hamaguchi M, Nagai T. A synthetic route to bicyclic pyrazolenines via 3-chloropyrazolines and the ring opening of pyrazolenines to diazoalkenes. J Org Chem. 1989;54:5912-5919.

26. Foti F, Grassi G, Risitano F. First synthesis of a bromonitrilimine. Direct formation of 3-bromopyrazoles. Tetrahedron Lett. 1999;40: 2605-2606.

27. Deng X, Mani NS. Regioselective synthesis of 1,3,5-tri- and 1,3,4,5tetrasubstituted pyrazoles from $N$-arylhydrazones and nitroolefins. J Org Chem. 2008;73:2412-2415.

28. Gelin S, Chantegral A, Nadi A, Fruchier A. Synthesis of 4-(acylacetyl)1-phenyl-2-pyrazolin-5-ones from 3-acyl-2H-pyran-2,4(3H)-diones. Their synthetic applications to functionalized 4-oxopyrano[2,3-c] pyrazole derivatives. J Org Chem. 1983;48:4078-4082.

29. Kumar D, Singh SP. The structure of the products resulting from dehydroacetic acid and hydrazines. J Indian Chem Soc. 2006;83:419-426.

30. Singh SP, Prakash O, Vaid RK. Reaction of 2-hydrazino-4-methyl-6methoxyquinoline with dehydroacetic acid: formation of some novel products. Indian J Chem. 1984;23B:191-192.

31. Kumar D, Singh SP, Martinez A, et al. The structure of the compounds resulting from the reaction of arylhydrazines and dehydroacetic acid: an NMR and crystallographic study. Tetrahedron. 1995;51: 4891-4906.

32. Wang S, Meades C, Wood G, et al. 2-Anilino-4-(thiazol-5-yl)pyrimidine CDK inhibitors: synthesis, SAR analysis, x-ray crystallography and biological activity. J Med Chem. 2004;47:1662-1675.

33. Orjales A, Mosquera R, Lopez B, Olivera R, Labeaga L, Nunez MT. Novel 2-(4-methylsulfonylphenyl)pyrimidine derivatives as highly potent and specific COX-2 inhibitors. Bioorg Med Chem. 2008;16:2183-2199.

34. Kosolapoff GM, Roy CH. Synthesis of some pyrimidylphosphonates. J Org Chem. 1961;26:1895-1898.

35. KatzL.Antituberculous compounds. II. 2-benzalhydrazinobenzothiazoles. J Am Chem Soc. 1951;73:4007-4010.

36. Takahiro S, Takayaki O, Hisashi O, Satoshi M, inventors; Kyowa Hakko Chemicals Co, Ltd. Optical recording medium containing the same compound and complex. Japanese patent JP 2011126815. June 30, 2011.

37. Perez C, Paul M, Bazerque P. An antibiotic assay by the agar well diffusion method. Acta Bio Med Exp. 1990;15:113-115.

38. National Committee for Clinical Laboratory Standards. Methods for Dilution Antimicrobial Susceptibility Tests for Bacteria that Grow Aerobically: Approved Standards, 6th ed. Villanova, PA: National Committee for Clinical Laboratory Standards Document M7-A6; 2003.

\section{Dovepress}

\section{Publish your work in this journal}

Reports in Organic Chemistry is an international, peer-reviewed, open access journal publishing original research, reports, reviews and commentaries on all areas of organic chemistry. The manuscript management system is completely online and includes a very quick and fair peer-review system, which is all easy to use. Submit your manuscript here: http://www.dovepress.com/reports-in-organic-chemistry-journal
Visit http://www.dovepress.com/testimonials.php to read real quotes from published authors. 